\title{
Rejection of the Type Species Methanosarcina methanica (Approved Lists 1980), Conservation of the Genus Methanosarcina with Methanosarcina barkeri (Approved Lists 1980) as the Type Species, and Emendation of the Genus Methanosarcina
}

\author{
Request for an Opinion \\ ROBERT A. MAH ${ }^{1 *}$ AND DAISY A. KUHN ${ }^{2}$ \\ Division of Environmental and Occupational Health Sciences, School of Public Health, University of California, Los \\ Angeles, California $90024^{1}$ and Department of Biology, California State University, Northridge, California $91330^{2}$
}

We request an Opinion regarding rejection of the type species Methanosarcina methanica (Approved Lists 1980) and conservation of the genus Methanosarcina with Methanosarcina barkeri (Approved Lists 1980) as the type species, and we provide an emended description of the genus Methanosarcina.

The type species of the genus Methanosarcina is Methanosarcina methanica (Smit 1930) Kluyver and van Niel 1936, as listed on the Approved Lists of Bacterial Names (10), which became effective on 1 January 1980 . Our current understanding of methanogenic bacteria indicates an organism fitting the description of Methanosarcina methanica (3) will not be found in nature. Methanogenic bacteria are not known to use butyrate (9), which was reported to be the distinctive characteristic of Methanosarcina methanica. Thus, we request an Opinion from the Judicial Commission of the International Committee on Systematic Bacteriology that the specific epithet of Methanosarcina methanica, the nomenclatural type species of the genus Methanosarcina, be placed on the list of epithetica specifica rejicienda because it is a nomen dubium et confusum according to Rules $20 \mathrm{e}$ and $56 \mathrm{a}$ of the International Code of Nomenclature of Bacteria (6).

Since this genus would cease to exist by this action (Rule 37a), we respectfully request that the Judicial Commission of the International Committee on Systematic Bacteriology issue an Opinion to conserve the genus Methanosarcina Kluyver and van Niel 1936 emend. Barker 1956 (4), with Methanosarcina barkeri Schnellen 1947 as the type species (Rule 20e).

In 1979, before the publication of the Approved Lists of Bacterial Names (10), Balch et al. (2) chose Methanosarcina barkeri Schnellen 1947, 73 (C. G. T. P. Schnellen, Ph.D. thesis, Delft University of Technology, Delft, The Netherlands, 1947) as the type species of the genus Methanosarcina since Methanosarcina methanica was not included in the first draft of the Approved Lists of Bacterial Names (1) in 1976 and since it had not been cultivated axenically.

In addition, reclassification of Methanococcus mazei to the genus Methanosarcina as Methanosarcina mazei (8) requires emendation of the genus Methanosarcina to include the morphological variations (introduced by this taxonomic change) observed by Mah (7) and Zhilina and Zavarzin (11) and to reflect current physiological information, especially regarding substrate utilization.

The methanogenic substrates are now known to include

\footnotetext{
* Corresponding author.
}

mono-, di-, and trimethylamines (5); however, butyrate is not a methanogenic substrate (9). The deoxyribonucleic acid base compositions of 29 strains of Methanosarcina species, including the five strains reported by Balch et al. (2), range from 40 to $43 \mathrm{~mol} \%$ guanine plus cytosine (I. Yu, H. Negoro, and R. A. Mah, unpublished data), as determined by the buoyant density method.

Species in the genus Methanosarcina differ from species in the genus Methanococcus not only in morphology, but also in their ability to utilize acetate, methanol, and mono-, di-, and trimethylamines, which are not metabolized by Methanococcus species. Members of both genera use $\mathrm{H}_{2^{-}}$ $\mathrm{CO}_{2}$.

An emended description of the genus Methanosarcina is given below.

Methanosarcina Kluyver and van Niel 1936, 400 (Approved Lists 1980) emend. Mah and Kuhn 1984 (Me.tha.nosar.ci'na. M.L. n. methanum methane; L. n. sarcina a package, bundle; M.L. n. Methanosarcina methane sarcina). Small to large spheroid bodies comprised of many irregular units. The multilocular nature is visible only by transmission electron microscopy of thin sections, although phase-contrast microscopy reveals some surface indentations. The spheroid bodies may exist as (i) small coccoid shapes 1 to $3 \mu \mathrm{m}$ in diameter, with a tendency to irregularity, (ii) larger coccoid bodies 5 to $10 \mu \mathrm{m}$ in diameter, occurring in clusters of 5 to 10 or more, and (iii) large spheroid bodies 20 to $100 \mu \mathrm{m}$ or more in diameter. Under phase-contrast microscopy, these latter bodies appear to be comprised of segmented compartments. Occasionally, these bodies may aggregate to form large rafts that are $1,000 \mu \mathrm{m}$ or more across. A cyst with a common outer layer may enclose myriads of small irregular coccoid elements. Such cysts may be ruptured by applying external pressure or may rupture spontaneously to release the coccoid elements. A life cycle involving these forms may occur. Gas vesicles may occur. Gram stain results are variable. Nonmotile.

Very strict anaerobes. Energy metabolism by formation of methane from acetate, methanol, mono-, di-, and trimethylamines, $\mathrm{H}_{2}-\mathrm{CO}_{2}$, and possibly $\mathrm{CO}$. Growth temperature ranges from 25 to $45^{\circ} \mathrm{C}$ and from 35 to $55^{\circ} \mathrm{C}$. The optimal growth temperatures are $37^{\circ} \mathrm{C}$ for mesophiles and $50^{\circ} \mathrm{C}$ for moderate thermophiles.

The deoxyribonucleic acid base composition ranges from 
40 to 43 mol\% guanine plus cytosine, as determined by the buoyant density method.

The type species is Methanosarcina barkeri Schnellen 1947, 73.

\section{ACKNOWLEDGMENT}

We thank David R. Boone for perusing our manuscript.

\section{LITERATURE CITED}

1. Ad Hoc Committee of the Judicial Commission of the ICSB. 1976. First draft. Approved lists of bacterial names. Int. J. Syst. Bacteriol. 26:563-599.

2. Balch, W. E., G. E. Fox, L. J. Magrum, C. R. Woese, and R. S. Wolfe. 1979. Methanogens: reevaluation of a unique biological group. Microbiol. Rev. 43:260-296.

3. Barker, H. A. 1936. Studies upon the methane-producing bacteria. Arch. Mikrobiol. 7:420-438.

4. Bryant, M. P. 1974. Methane-producing bacteria, p. 472-477. In R. E. Buchanan and N. E. Gibbons (ed.), Bergey's manual of determinative bacteriology, 8 th ed. The Williams \& Wilkins Co., Baltimore.

5. Hippe, H., D. Caspari, K. Fiebig, and G. Gottschalk. 1979. Utilization of trimethylamine and other $\mathrm{N}$-methyl compounds for growth and methane formation by Methanosarcina barkeri. Proc. Natl. Acad. Sci. U.S.A. 76:494-498.

6. Lapage, S. P., P. H. A. Sneath, E. F. Lessel, V. B. D. Skerman, H. P. R. Seeliger, and W. A. Clark (ed.). 1975. International code of nomenclature of bacteria. 1975 Revision. American Society for Microbiology, Washington, D.C.

7. Mah, R. A. 1980. Isolation and characterization of Methanococcus mazei. Curr. Microbiol. 3:321-326.

8. Mah, R. A., and D. A. Kuhn. 1984. Transfer of the type species of the genus Methanococcus to the genus Methanosarcina, naming it Methanosarcina mazei (Barker 1936) comb. nov. et emend. and conservation of the genus Methanococcus (Approved Lists 1980) with Methanococcus vannielli (Approved Lists 1980) as the type species. Request for an Opinion. Int. J. Syst. Bacteriol. 34:263-265.

9. McInerney, M. J., M. P. Bryant, R. B. Hespell, and J. W. Costerton. 1981. Syntrophomonas wolfei gen. nov., sp. nov., an anaerobic, syntrophic, fatty acid-oxidizing bacterium. Appl. Environ. Microbiol. 41:1029-1039.

10. Skerman, V. B. D., V. McGowan, and P. H. A. Sneath (ed.). 1980. Approved lists of bacterial names. Int. J. Syst. Bacteriol. 30:225-420.

11. Zhilina, T. N., and G. A. Zavarzin. 1979. Cyst formation by Methanosarcina. Microbiology (USSR) 48:349-354. 